FLIES AND DISEASE, Volume I

Ecology, Classification, and Biotic Associations 



\section{FLIES AND DISEASE}

Volume I $\begin{gathered}\text { ECoLOGY, CLASSIFCATION } \\ \text { AND BIOTIC ASSOCIATIONS }\end{gathered}$ BY BERNARD GREENBERG

Princeton University Press, Princeton, New Jersey 1971

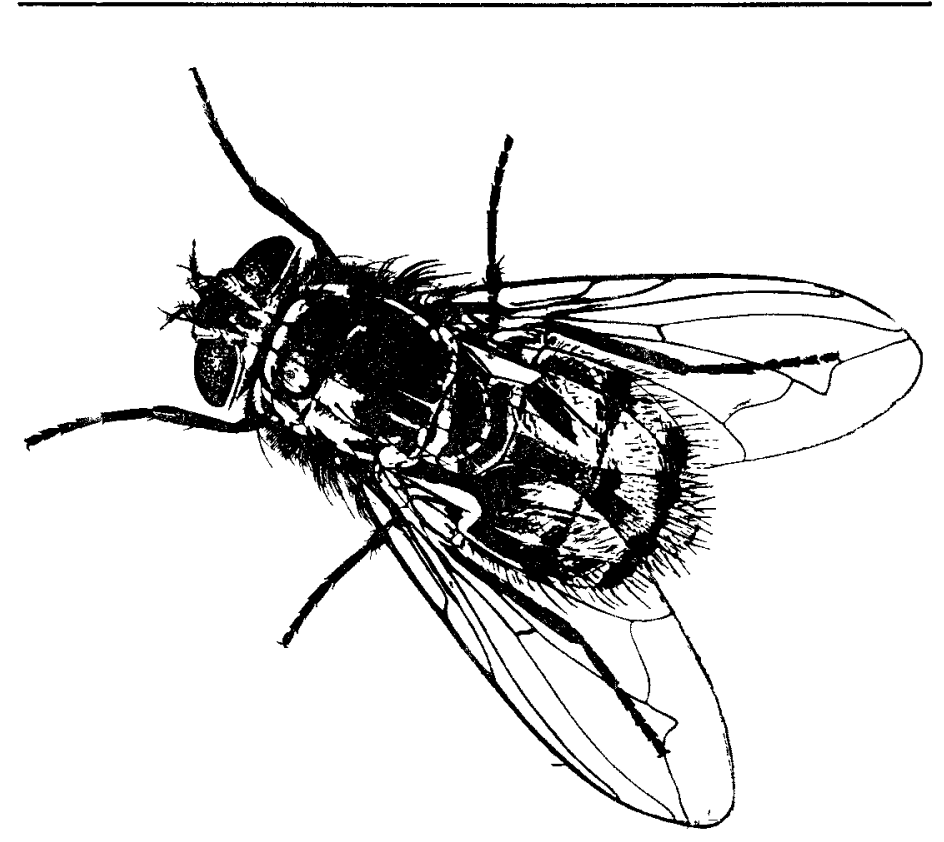


COPYRIGHT (c) 1971 BY PRINCETON UNIVERSITY PRESS. ALL rights reserved, L.C. Card: 68-56310. ISBN: 0-691-08071-2. Printed in the United States of America by Princeton University Press. This book has been composed in Linotype Times Roman.

Publication of this book has been aided by grants DA-MD-59-193-67-G9225, DADA-17-69-G-9225, and DADA-17-70-G-9313 from the U.S. Army Medical Research and Development Command.

Princeton Legacy Library edition 2019

Paperback ISBN: 978-0-691-65508-6

Hardcover ISBN: 978-0-691-65589-5 
To my wife, Barbie 
